Noe å lære av

\title{
En pasient med aortastenose og redusert venstre ventrikkel-funksjon
}

\author{
En 78 år gammel mann ble henvist til Rikshospitalet for utredning \\ av aortastenose avdekket ved lokalsykehus. Han var tidligere nyre- \\ transplantert og hadde i de senere år utviklet symptomer på hjertesvikt. \\ I tillegg til aortastenose hadde han betydelig redusert venstre ven- \\ trikkel-funksjon.
}

Se kommentar side 2121 og kunnskapsprøve på www.tidsskriftet.no/quiz

Pasienten hadde de siste årene utviklet hjertesvikt med dyspné i NYHA klasse II-III og asteni. Mest plaget var han imidlertid av uttalte residiverende underekstremitetsødemer. Han hadde også utviklet persisterende atrieflimmer. Det var ingen kjent opphopning av hjertesykdom i familien. Han hadde angivelig fått påvist proteinuri allerede $i$ ungdommen. 20 år før den aktuelle innleggelsen ble han nyretransplantert pga. nyresvikt forårsaket av nefrosklerose. Transplantatet hadde vært velfungerende, men kreatininnivået hadde den siste tiden vært lett forhøyet 1120-150 $\mu \mathrm{mol} / \mathrm{l}$, svarende til en glomerulær filtrasjonsrate på 40-50 $\mathrm{ml} / \mathrm{min}$ ).

Pasienten hadde hatt flere innleggelser ved lokalsykehuset pga. forverring av hjertesvikten. Ekkokardiografi viste alvorlig aortastenose og fortykket myokard. Han ble henvist til Rikshospitalet for utredning og ev. behandling av klaffefeilen.

Aortastenose er den hyppigst forekommende klaffelidelsen i den vestlige verden (1). Hos majoriteten av pasientene er årsaken degenerativ klaffesykdom, som er assosiert med de klassiske risikofaktorer for aterosklerose: hypertensjon, røyking, hyperkolesterolemi og høy alder (2). Oftest har pasienten en lang symptomfri periode før venstre ventrikkel svikter. Mange utvikler venstre ventrikkelhypertrofi som følge av økt trykkbelastning (afterload). Hos enkelte ses redusert venstre ventrikkel-funksjon forårsaket av stenosen.

Når aortastenosen blir symptomgivende, er prognosen dårlig (3). Etter kirurgisk implantasjon av klaffeprotese er imidlertid prognosen meget god - den forventede levealder er tilnærmet lik levealderen i den aldersjusterte befolkningen for øvrig (4). Pasienter med antatt symptomgivende aortastenose skal derfor vurderes med tanke på klaffekirurgi.

Ved første innleggelse ved Hjertemedisinsk avdeling, Rikshospitalet, hadde pasienten bilaterale ankelødemer og stenoselyd grad 4/4 over hjertet, forenlig med aortastenose. Annen hjertetone var opphevet. Blodtrykket var $110 / 92 \mathrm{~mm} \mathrm{Hg}$, pulsen $76 \mathrm{slag} / \mathrm{min}$ og uregelmessig. EKG viste atrieflimmer og venstre ventrikkel-hypertrofi, med ST-depresjoner anterolateralt. Blodprøver viste et kreatininnivå på $142 \mu \mathrm{mol} / \mathrm{l}$, svarende til en estimert glomerulær filtrasjonsrate på $42 \mathrm{ml}$ min og nyresvikt stadium 3. Urea var tilsvarende forhøyet - 19,7 mmol/l. For øvrig var prøvesvarene relativt upåfallende - SR 15, $\mathrm{Hb}$ $15,8 \mathrm{~g} / 100 \mathrm{ml}$, trombocytter $224 \cdot 10^{\%} / \mathrm{l}$, leukocytter $6,4 \cdot 10^{9} / \mathrm{l}$, natrium $147 \mathrm{mmol} / \mathrm{l}$, kalium 4,0 mmol/l og glukose 5,5 mmol/l. Ekkokardiografi viste moderat dilatert venstre ventrikkel med lett til moderat fortykket vegg. Endediastolisk indre diameter var $6,6 \mathrm{~cm}$, septumtykkelse $1,4 \mathrm{~cm}$ og bakre veggs tykkelse 1,2 cm (fig 1). Venstre ventrikkels ejeksjonsfraksjon ad modum Simpson biplan var ca. $30 \%$. Det var tegn til forhøyet venstresidig fyllingstrykk. Aortaklaffen var trikuspid med betydelig forkalkning av alle tre kusper, redusert åpningsbevegelse og betydelig aortastenose, med areal $0,9 \mathrm{~cm}^{2}$ beregnet etter kontinuitetslikningen. Det var en liten, sentral aortainsuffisiens. Mitralklaffen hadde slanke segl og en liten insuffisiens. Det forelå biatrial forstørrelse lvenstre atrium 29,5 $\mathrm{cm}^{2}$, høyre atrium 20,5 $\mathrm{cm}^{2}$ ). Blodstrømshastigheter $i$ mitralostiet, vevshastigheter $i$ mitralringen og dilatert venstre atrium indikerte samlet at det forelå restriktiv fylling av venstre ventrikkel. Myokard hadde et påfallende, granulært ekkokardiografisk uttrykk, og det ble mistenkt primær myokardsykdom i tillegg til klaffefeil. Koronarangiografi viste kalk i proksimale koronarkar, men ingen signifikante stenoser.

Nedsatt funksjon av venstre ventrikkel utgjør ingen absolutt kontraindikasjon når det gjelder klaffekirurgi ved aortastenose. Tvert imot kan svekkelse av venstre ventrikkel være indikasjon for kirurgisk intervensjon ved aortastenose (1). Oftest vil venstre ventrikkels funksjon ta seg opp etter vellykket
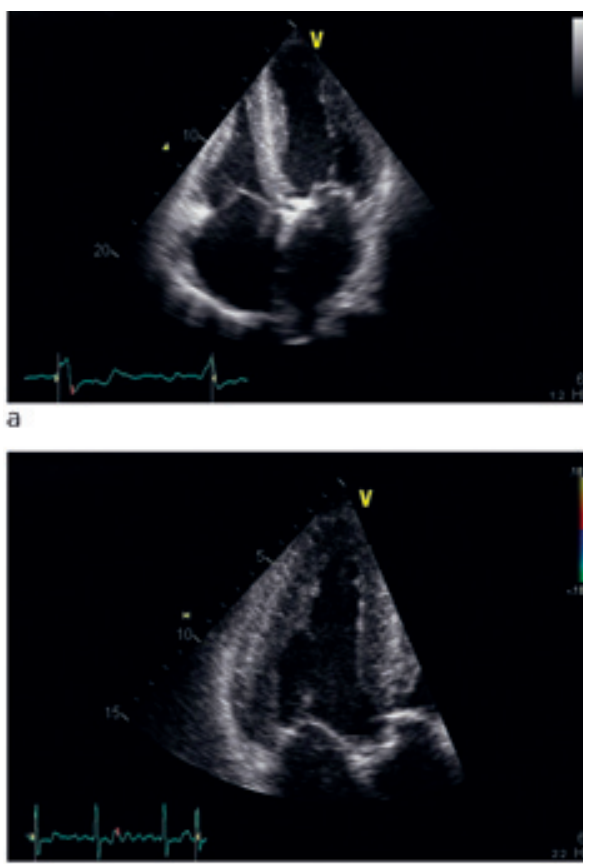

b

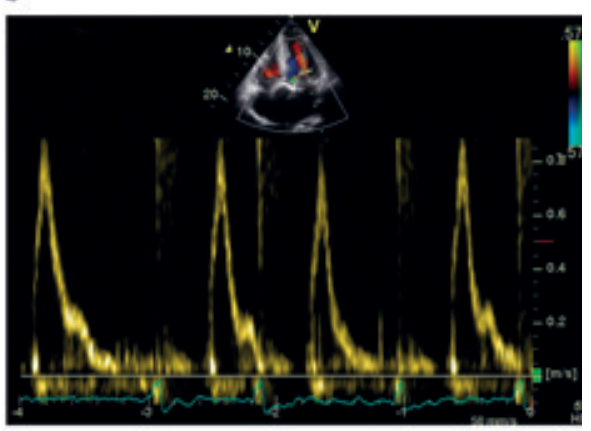

c

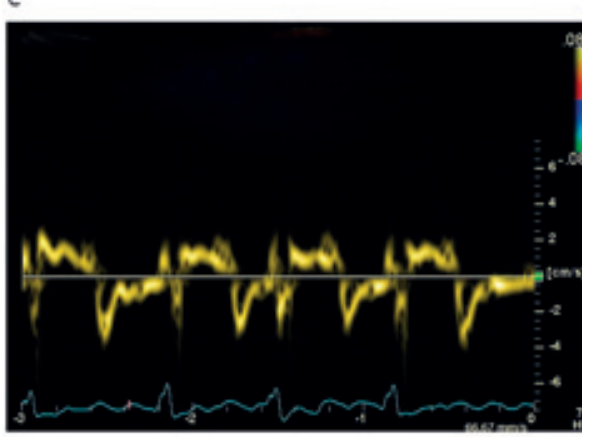

d

Figur 1 Ekkokardiografi. al Apikalt firekammerbilde viser fortykket venstre ventrikkelvegg, granulært mønster i myokard og biatrial dilatasjon.

b) Apikalt langaksebilde i midtsystole viser sklerotisk aortaklaff uten synlig åpning. c) Pulset doppler imitralostiet viser blodstrømshastigheter med kort deselerasjonstid (124 ms). Pasienten har atrieflimmer. d) Pulset vevsdoppler av septale mitralring viser nedsatt langaksebevegelighet $i$ systole $\left(S_{1}=\right.$ $0,02 \mathrm{~m} / \mathrm{sek})$ og tidlig diastole $\left(E^{\prime}=0,04 \mathrm{~m} / \mathrm{sek}\right)$ 


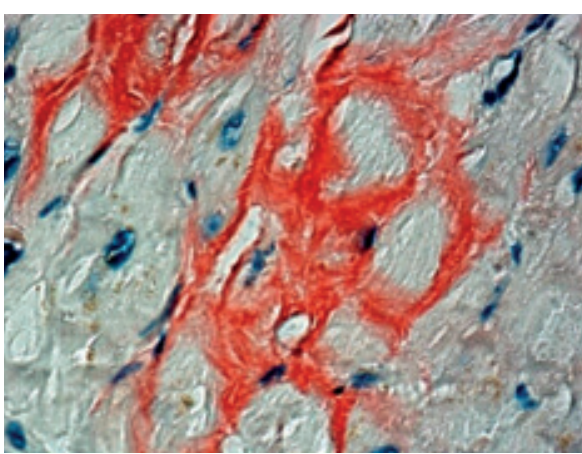

Figur 2 Endomyokardial biopsi. Snittet er farget med kongorødt og viser nedslag av amyloid mellom myocyttene

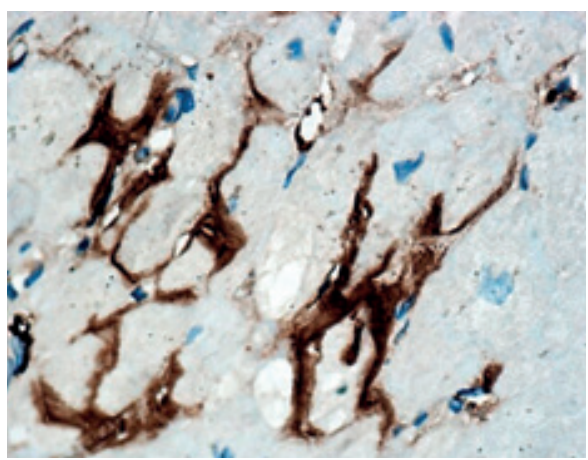

Figur 3 Endomyokardial biopsi. Immunhistokjemisk behandling med antistoffer rettet mot transtyretin viser ekstracellulær avleiring av dette proteinet

kirurgi (5). Dette forutsetter at hjertesvikten er sekundær til stenosen. I dette tilfellet ga ekkokardiografisk undersøkelse mistanke om at pasientens hjertesvikt ikke alene skyldtes klaffelidelsen, men at han også hadde en myokardial sykdom. Det er viktig å avdekke årsaken til og graden av slik sykdom før man tar beslutning om ev. kirurgi.

Grunnet betydelig svekket venstre ventrikkel ble det besluttet at pasienten skulle få utført stressekkokardiografisk undersøkelse for vurdering av venstre ventrikkels kontraktile reserve. Han ble skrevet ut til hjemmet $i$ mellomtiden.
Stressekkokardiografi kan avdekke om en aortaklaff med lavt beregnet areal virkelig er så trang (fiksert) eller om den bare åpner seg dårlig pga. nedsatt ventrikkelfunksjon (5). Stressekkokardiografi har også vist seg nyttig i å kunne avgjøre om venstre ventrikkel har kontraktile reserver, hvorved man kan forvente bedret funksjon etter ventilkirurgi. Manglende kontraktil reserve predikerer høy operativ risiko (5).

I forkant av neste innleggelse hadde pasienten vært innlagt ved lokalsykehuset for diuretisk behandling og optimalisering av hjertesviktmedikasjonen. Vekten gikk i løpet av dette oppholdet ned med ca. $10 \mathrm{~kg}$. Ved innleggelse ved Rikshospitalet var han tilbake $i$ habitualtilstand.

Stressekkokardiografi med gradert dobutaminbelastning til $20 \mu \mathrm{g} / \mathrm{kg} / \mathrm{min}$ viste fiksert stenose med beregnet areal $0,7 \mathrm{~cm}^{2}$ (tab 1). Venstre ventrikkels systoliske funksjon var som tidligere betydelig nedsatt. Det ble ingen bedring av systolisk funksjon ved belastning.

Den stressekkokardiografiske undersøkelsen viste at pasientens aortastenose var fiksert, men også at venstre ventrikkel manglet kontraktil reserve. Årsaken til at venstre ventrikkel var hypertrofisk, restriktiv og svekket var imidlertid ikke funnet.

Transvenøs biopsi av endomyokard viste avleiring av amyloid (fig 2), der immunohistokjemisk fremstilling avdekket nedslag av transtyretin (prealbumin) (fig 3).

Etter en diskusjon som involverte kardiologer og thoraxkirurger ved Rikshospitalet, ble det besluttet ikke å tilby vår pasient operasjon. Høy alder, status med nyretransplantat og nyresvikt gir i seg selv forhøyet operativ risiko. Hans betydelig svekkede venstre ventrikkel uten kontraktil reserve ble ansett å utgjøre en så stor tilleggsrisiko at operasjon ikke kunne tilrådes. Han ble derfor skrevet ut til hjemmet med uendret medikamentell behandling og oppfølging ved lokal hjertesviktpoliklinikk.

Tabell 1 Stressekkokardiografi med gradert dobutaminbelastning. Tabellen viser at aortastenosen er fiksert - åpningsarealet (beregnet etter kontinuitetslikningen) forblir uendret. Det fremkommer også at venstre ventrikkel mangler kontraktil reserve - slagvolumet forblir lavt og trykkgradienten over aortaklaffen stiger lite på tross av økende dobutaminstimulus. Minuttvolumet $ø$ ker noe parallelt med stigende hjertefrekvens

\begin{tabular}{|lccc|}
\hline Hjertefrekvens (slag/min) & $\begin{array}{c}\text { Dobutamin } \\
(\mu \mathrm{g} / \mathrm{kg} / \mathrm{min})\end{array}$ & $\begin{array}{c}\text { Dobutamin } \\
(\mu \mathrm{g} / \mathrm{kg} / \mathrm{min})\end{array}$ & $\begin{array}{c}\text { Dobutamin } \\
(\mu \mathrm{g} / \mathrm{kg} / \mathrm{min})\end{array}$ \\
\hline Systolisk/diastolisk blodtrykk $(\mathrm{mm} \mathrm{Hg})$ & 0 & 10 & 20 \\
\hline Venstre ventrikkels slagvolum $(\mathrm{ml})$ & 69 & 69 & 117 \\
\hline Minuttvolum (l/min) & $49 / 72$ & $86 / 52$ & $101 / 64$ \\
\hline Gjennomsnittlig trykkgradient over aortaklaff $(\mathrm{mm} \mathrm{Hg)}$ & 3,0 & 57 & 48 \\
\hline Beregnet aortaklaffareal $\left(\mathrm{cm}^{2}\right)$ & 26 & 29 & 5,6 \\
\hline
\end{tabular}

\section{Diskusjon}

Amyloidose er en tilstand karakterisert ved nedslag av monomorft proteinmateriale $\mathrm{i}$ ett eller flere vev. Dette materialet gir et karakteristisk «eplegrønt» skimmer når det farges med kongorødt og betraktes i polarisert lys. Flere naturlig forekommende og muterte proteiner har evnen til å danne amyloid. Etter molekylærbiologiske fremskritt kan man nå skille mellom en rekke typer amyloidose ut fra hvilket protein som felles ut (6). De viktigste systemiske formene for amyloidose er amyloid lettkjede (AL)-amyloidose (tidligere kalt «primær» amyloidose), forårsaket av nedslag av lette kjeder ved monoklonal plasmacelleproliferasjon, og amyloid A-protein (AA)-amyloidose («sekundær» amyloidose). Ved sistnevnte er det nedslag av et leversyntetisert akuttfaseprotein ved langvarig inflammatorisk tilstand (6).

Den vanligste form for kardial amyloidose er imidlertid amyloid transtyretin (ATTR)-amyloidose, også kalt senil systemisk amyloidose. Denne formen for amyloidose forårsakes av utfelling av transtyretin (tidligere kalt prealbumin) (7). Prevalensen av slik amyloidose $\mathrm{i}$ autopsimaterialer hos eldre er angitt å være ca. $25 \%$ (8). Langt de fleste tilfeller er asymptomatiske. Selv symptomgivende kardial ATTR-amyloidose har langt bedre prognose enn f.eks. ALamyloidose, med en forventet levetid på 5-6 år versus under 12 måneder (9).

Kardial amyloidose medfører ofte EKGforandringer, mest typisk ses små elektriske amplituder i standardavledningene (low voltage). Funnet er imidlertid ikke patognomonisk (9) og fantes ikke hos vår pasient. Ekkokardiografisk ses fortykkelse av myokard med typisk ekkogenisitet og restriktivt fyllingsmønster (10). For sikkert å kunne stille diagnosen kreves imidlertid biopsi ved systemisk sykdom kan biopsi tas fra rectum eller abdominalt fettvev. Imidlertid er sensitiviteten ved biopsi i ekstrakardialt vev lav ved ATTR-amyloidose (9).

Hos vår pasient fant man betydelig nedslag av transtyretin i myokard. Dette ses ved to tilstander: Ved arvelig sykdom forårsaket av mutasjon i genet for transtyretin, noe som gir hjertesvikt og polynevropati i relativt ung alder, og ved senil systemisk amyloidose, der det utfelles «villtype» (normalt) transtyretin. Denne tilstanden gir kardial amyloidose i høy alder, vanligvis uten sikre symptomer (7). Vår pasient hadde verken nevropati, sykdomsdebut i ung alder eller familiær forekomst av amyloidose eller uforklart hjertesvikt. Vi fant det derfor sannsynlig at han hadde den vanlige, ikke-arvelige varianten av amyloidose med nedslag av normalt transyretin. Det ble ikke gjort elektroforese eller genetisk testing med tanke på ev. mutasjon, da slik diagnostikk ikke utføres i Norge.

Både aortastenose og (subklinisk) kardial amyloidose er hyppig forekommende tilstander i den eldre del av befolkningen. Pro- 
blemstillingen med samtidig forekommende alvorlig aortastenose og symptomgivende kardial amyloidose er imidlertid lite omtalt $i$ litteraturen. Ved søk i PubMed på «amyloidosis» AND («aortic stenosis» OR «aortic valve stenosis») oppnås bare 35 treff (10.6. 2009), hvorav flertallet av artiklene omhandler de to tilstandene som differensialdiagnoser ved hjertesvikt. Kun én artikkel handler om amyloidavleiring i hjerteklaffer (11). Der fremkommer det at pasienter med familiær amyloidose med polynevropati har nedslag av amyloid også i hjerteklaffene. Imidlertid hadde kun to av 12 pasienter i dette obduksjonsmaterialet signifikant klaffestenose, hvorav én stenotisk aortaklaff var bikuspid. Begge de stenotiske klaffene hadde betydelig forkalkning, der kalknedslaget ikke samsvarte med fordelingen av amyloid i én og samme klaff. Det er således ingen beskrevet sammenheng mellom kardial amyloidose og aortastenose, men temaet er lite belyst.

Denne kasuistikken setter søkelys på en lite omtalt sykdomskombinasjon: aortastenose og amyloidose. Den understreker også viktigheten av grundig utredning og vurdering før beslutning om større hjertekirurgi tas. Stressekkokardiografi med dobutamin- belastning var en avgjørende undersøkelse i den diagnostiske prosessen.

\section{Pasientens pårørende har gitt samtykke} til at artikkelen blir publisert.

\section{Kaspar Broch}

kaspar.broch@rikshospitalet.no Einar Gude

Hjertemedisinsk avdeling

Rikshospitalet

0027 Oslo

\section{Helge Scott}

Avdeling for patologi

Svend Aakhus

Hjertemedisinsk avdeling

Rikshospitalet

\section{Oppgitte interessekonflikter: Ingen}

\section{Litteratur}

1. Vahanian A, Baumgartner H, Bax J et al. Guidelines on the management of valvular heart disease: the Task Force on the Management of Valvular Heart Disease of the European Society of Cardiology. Eur Heart J 2007; 28: 230-68.

2. Stewart BF, Siscovick D, Lind BK et al. Clinical factors associated with calcific aortic valve disease. Cardiovascular Health Study. J Am Coll Cardiol 1997: 29: 630-4

3. Ross J jr., Braunwald E. Aortic stenosis. Circulation 1968; 38: 61-7
4. Kvidal P, Bergstrom R, Horte LG et al. Observed and relative survival after aortic valve replacement. J Am Coll Cardiol 2000; 35: 747-56.

5. Nishimura RA, Grantham JA, Connolly HM et al. Low-output, low-gradient aortic stenosis in patients with depressed left ventricular systolic function: the clinical utility of the dobutamine chal lenge in the catheterization laboratory. Circulation 2002: 106: 809-13.

6. Westermark P, Benson MD, Buxbaum JN et al. A primer of amyloid nomenclature. Amyloid 2007 . 14: $179-83$

7. Shah KB, Inoue Y, Mehra MR. Amyloidosis and the heart: a comprehensive review. Arch Intern Med 2006: 166: 1805-13.

8. Cornwell GG, Murdoch WL, Kyle RA et al. Frequency and distribution of senile cardiovascular amyloid. A clinicopathologic correlation. Am J Med 1983: 75: 618-23.

9. $\mathrm{Ng} \mathrm{B}$, Connors LH, Davidoff R et al. Senile systemic amyloidosis presenting with heart failure: a comparison with light chain-associated amyloidosis. Arch Intern Med 2005; 165: 1425-9.

10. Siqueira-Filho AG, Cunha CL, Tajik AJ et al. $M$-mode and two-dimensional echocardiographic features in cardiac amyloidosis. Circulation 1981; 63: $188-96$

11. Eriksson A, Olofsson BO, Eriksson P. Heart valve involvement in familial amyloidosis with polyneuropathy. Pathol Res Pract 1986; 181: 563-7.

Manuskriptet ble mottatt 4.12. 2008 og godkjent 18.6. 2009. Medisinsk redaktør Odd Terje Brustugun.

\section{Kommentar}

\section{En diagnose som krever biopsi}

Det har stor betydning for pasienter med amyloidose at diagnosen blir stilt. Mens man lenge betraktet amyloidavleiring som en irreversibel prosess med meget dårlig prognose, er det i senere år vist at dette er en dynamisk og påvirkelig utvikling og at avleiret amyloid kan gå tilbake. Behandling kan gi bedre overlevelse og høyere livskvalitet ved flere typer amyloidose (1). For å stille diagnosen kreves biopsi av affisert vev, og klinisk mistanke er dermed avgjørende. Alle kroppens organer kan rammes av ulike typer amyloidose, og diagnostikk av amyloidose er aktuelt innenfor de fleste medisinske spesialiteter. Amyloidose blir dessverre ofte oversett in vivo.

Broch og medarbeideres kasuistikk illustrerer hvordan grundig utredning, her ut fra mistanke om primær myokardsykdom, førte til at man tok biopsi, og også hvordan amyloiddiagnosen fikk konsekvenser for den videre behandling, i dette tilfellet $\mathrm{i}$ vurderingen av operativ risiko. I andre tilfeller vil diagnosen gi mulighet for aktiv behandling. Amyloid avleires ekstracellulært enten i ett organ/organsystem (ved lokaliserte amyloidoser) eller i flere organsystemer (ved systemiske amyloidoser). Systemisk amyloidose bør være med i den differensialdiagnostiske tankegang ved uforklart multiorgansykdom og manifestasjoner som vekttap, slapphet, proteinuri, restriktiv kardiomyopati, hepatomegali, gastrointestinale eller pulmonale symptomer, hudaffeksjon og nevropati (2). Biopsi bør primært tas fra symptomgivende organ, men det er i mange tilfeller fornuftig å starte med mindre invasiv prøvetaking fra organer som hyppig er affisert av systemisk amyloidose, som hud eller tarmslimhinne (3).

Når amyloid er bekreftet i biopsi ved farging med kongorødt, er det avgjørende å gjøre typing av amyloidet, slik at man kan gi spesifikk behandling og unngå feilbehandling med potensielt svært toksiske legemidler. Mer enn 25 ulike kroppsegne proteiner kan i sin normale form eller i muterte varianter avleires som amyloid i mennesker, og ved typing, først og fremst immunhistokjemisk, skiller man mellom de ulike amyloidproteinene. Ved mistanke om systemisk amyloidose starter man typingen mot de hyppigst forekommende systemiske amyloidosene AA-amyloidose, AL-amyloidose og transtyretinamyloidose (ATTR). Mens tilgjengelige antistoffer mot AA-amyloid har høy spesifisitet og sensitivitet, er sensitiviteten for AL-amyloidose ved immunhistokjemisk undersøkelse lav. I praksis blir ofte diagnosen AL-amyloidose stilt uten at ALamyloid er sikkert bekreftet i biopsien, noe som særlig ved tilstedeværelse av en monoklonal komponent av ukjent betydning (MGUS) lett kan føre til feil diagnose. I et materiale fra Storbritannia fant man at nesten $10 \%$ av 350 pasienter som var diagnostisert med AL-amyloidose ved nærmere gjennomgang viste seg å ha andre systemiske, i hovedsak arvelige, amyloidoser (4). Systemisk amyloidose som ved immunhistokjemisk undersøkelse er negativ for AA-, AL- og TTR-amyloid bør utredes med spesialundersøkelser som innebærer testing for andre amyloidproteiner. Det er foreslått at slik amyloidtyping bør samordnes innenfor de nordiske land (3).

For TTR-amyloidose, $\mathrm{i}$ form av systemisk senil amyloidose hvor normalt transtyretin danner amyloidfibriller, eksisterer det per i dag ingen kausal behandling - det sentrale blir god støttende behandling. Ved arvelige systemiske amyloidoser, hvor ulike mutasjoner øker tilbøyeligheten til transtyretin eller andre proteiner til å danne amyloidfi- 